\title{
PUBLICATION MISCONDUCT
}

\author{
Yogita Talwar ${ }^{1}$, Dr. S. Aravind ${ }^{2}$ \\ ${ }^{1}$ Assistant Librarian, Lovely Professional University, Phagwara, Punjab-144001 \\ Email: talwaryogita6@gmail.com \\ ${ }^{2}$ Librarian and Head, Central Library and Department of Library and Information Science, \\ G.T.N. Arts College (Autonomous), Dindigul, India. \\ Email id: aravind@gtnarts.org
}

\section{Manuscript Info}

Manuscript History

Received: 05 November 2020

Final Accepted: 22 December 2020

Published: 10 January 2021

Online Published: February 2021

DOI: http:/ / dx.doi.org/10.35337/EIJLITR.2021.1203

Corresponding Author E-mail:

talwaryogita6@gmail.com (Yogita Talwar ) aravind@gtnarts.org (Dr.S.Aravind )

(C) Yogita Talwar, Dr. S. Aravind The Author. This is an open access article under the terms of the Creative Commons Attribution License 4.0, which allows use, distribution and reproduction in any medium, provided the original work is properly cited.

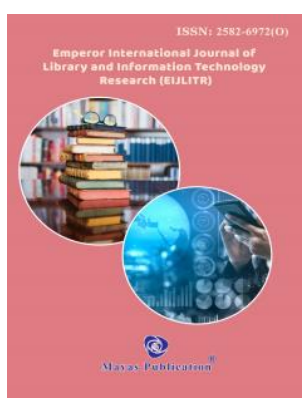

\section{Abstract}

Ethics is a moral position that enables society to pick what is correct or wrong. Moral subjects can be doled out into four pieces recommendations are meta-ethics, clarifying ethics, regularizing ethics and applied ethics. In an overall people moral standard is basically unclear for everybody. The explanation behind an ethical standard is to hold activity under phenomenal obligation. If all else fails moral standard is used in the genuine and genuine plan which sorts out what is correct and what's going on. By far most of the ethical rules stay consistent with time and they don't change throughout the timespan. There have a couple of clear events of smart burglary over two or three years.

Keywords: Ethics, Misconduct, Professional Ethics, COPE, WAME, Plagiarism unquestionable affirmation mechanical assemblages.

\section{INTRODUCTION}

The term is gotten from the Greek word ethos which can mean custom, inclination, character or air.

"The term ethics may suggest the philosophical examination of the thoughts of good and awful and great extraordinary and dreadful, to any philosophical speculation of what is morally acceptable and awful or morally incredible and horrible, and to any system or code of good principles, guidelines, or characteristics".

Larry Churchill has communicated: "Ethics, seen as the capacity to examine temperances and direct our exercises the extent that such characteristics, is a nonexclusive human cutoff." 


\section{Approaches to Ethics}

Realists nowadays will by and large partition moral speculations into three zones: Meta-ethics, normalizing ethics and applied morals.

\section{Ethical guidelines in science}

Several center standards (Resnik, 1993), including:

$>$ "Honesty in declaring of sensible data".

> "Careful record and examination of sensible results to keep an essential separation from botch".

$>$ "Independent examination and comprehension of results that relies upon data and not in view of outside sources".

$>$ "Open sharing of procedures, data, and understandings through appropriation and presentation".

$>$ "Sufficient endorsement of results through replication and collaboration with peers".

$>$ "Proper crediting of wellsprings of information, data, and musings".

> Moral responsibilities to society all around, and, in specific controls, commitment in checking the advantages of human and animal subjects".

\section{Principles for Good Scientific Practice}

While coordinating an incredible investigation, norms ought to be followed for satisfactory sensible practice. Inability to agree to the standards for extraordinary coherent practice may set up blemished assessment practice or reliable awful direct.

\section{According to Danish code of conduct}

Mind boggling genuine practice is depicted by three general standards: Honesty, straightforwardness and commitment.

\section{Set of recognized rules covers six fundamental bits of good reliable practice:}

$>$ Planning and driving investigation

$>$ Management of data

$>$ Publication and correspondence

$>$ Authorship

$>$ Collaborative investigation

$>$ Conflicts of interest

"Problematic investigation practice is portrayed in the law on consistent grievous conduct".

Questionable investigation practices are practices which may inimically influence the commonness of the assessment drove, or which at any rate may raise issues about its believability. Something central to get a handle on about risky assessment practices is that they may happen whether there is no presumption to mislead, at any rate considering carelessness. Events of risky assessment practice are;

$>$ Conscious or ignorant tendency

$>$ Sloppy research strategies or assessments

$>$ Ignoring moral rules

$>$ Denying attribution of creation to qualifying providers

\section{Research Integrity}

NAS report definition: "For individuals research decency is a piece of good character and experience. It incorporates over every one of the a guarantee to academic validity and good obligation with respect to ones exercises and to an extent of practices that depict able investigation lead." 


\section{Intellectual Honesty}

Insightful validity in proposing, performing, and uncovering research recommends unwavering quality as for the significance of one's investigation. It is customary that inspectors present proposal and data genuinely and give their best insight of the work recorded as a printed rendition and verbally.

Harvard ethicist Louis M. Guenin portrays the "part" of academic validity to be "a calm demeanor to disregard cheating when given a helper for interestingness"

\section{What is scientific misconduct?}

Coherent offense is a conscious or frightfully careless penetrate of the norms for consistent direct in sensible investigation. The law on genuine offense depicts this through three kinds of inadmissible direct.

$>$ Fabrication: Unreported improvement of information or exchange for whimsical data.

> "Creation is making up data or results and recording or uncovering them."

> Falsification: "Contortion is controlling assessment materials, stuff, or gauges, or changing or disregarding data or results so much that the investigation isn't absolutely tended to in the investigation record."

> Plagiarism: Without giving appropriate credit, if someone uses remarkable terms, considerations, text, cycles, data or delayed consequences of other individual, it is called falsifying.

According to Irving Hexham "Falsifying is the deliberate undertaking to deceive the peruser through the designation and depiction as one's own the work and articulations of others. Educational artistic robbery happens when a writer again and again usages various words from a printed source without the use of statements and a definite reference to the principal source in a work presented as the essayist's own assessment and award. Predictable rephrasing without certified collaboration with another person's points of view, by way or dispute or the development of new material land encounters, is a kind of copyright encroachment in academic work".

\section{Redundant Publication}

A silly practice where similar theory, data, discussion centers, or end is split between at any rate two papers (research correspondences), without full cross-reference.

\section{Duplicate, Overlapping publication and Salami slicing}

Experts' re-utilization of (portions of) their own past assessment conveyances or the material on which these appropriations are based offers ascend to various credible and investigation moral considerations. In this affiliation various kinds of cases can be perceived:

$>$ Publication of a near substance more than once (authentic duplicate conveyance)

$>$ Publication of a couple of intelligent things dependent on (genuinely) similar material or scattering (fairly) near outcomes (covering circulations)

$>$ Re-utilization of own substance, structure, insights, interpretations, and so on (self-forging)

\section{Actual duplicate publishing}

Certified duplicate circulating without an undeniable sign that the sythesis being suggested has been conveyed ahead of time is usually considered to include an infiltrate of good coherent practice. Different journals require that submitted interesting copies have not been actually appropriated (or uncovered). On the off chance that they perceive discretionary circulations, there are sometimes unequivocal guidelines controlling these.

Genuine duplicate circulating a significant part of the time requires endorsement from the distributer/journal that as of late conveyed the article, and so forth On the off chance that the manuscripit has various producers, certifiable duplicate appropriation will comparatively require the assent of the general large number of creators. This is an aftereffect of copyright rules. 


\section{Overlapping publications}

A specific cover between an expert's assessment disseminations isn't unusual in different coherent fields. For instance, a couple of circulations might be set up on a near material (research data) or spread (not completely) practically identical outcomes. In explicit spaces inspectors may even be said to have an essential fervor for dispersing their assessment in least publishable units, declared salami conveying.

The 'cutting' of assessment that would shape one critical paper into a couple of unquestionable papers is called 'salami conveyance' or 'salami cutting'. Rather than duplicate dispersion, which revealed accurately a comparative information for in any occasion two appropriations, salami cutting consolidates detaching or separating a gigantic report into at any rate two transports. These pieces are hinted as 'cuts' of an assessment.

While utilizing one's own work ... in a dispersion, sensible and definite references to such work ought to be given.

While using one's own work ... in a dispersion, fitting and definite references to such work should be given.

\section{What is Reporting Bias or selective reporting?}

Announcing inclination (particular revealing) impacts which considers "become exposed" and which don't. Studies might be picked (or not decided) for a swarm of reasons including singular plans, nonappearance of data, or messy examination strategies. Such an inclination is a liberal issue in logical enumerating and clinical preliminary detailing.

Revealing inclination suggests that singular a selection of results are associated with any investigation, which conventionally covers simply a modest quantity of relevant evidence. This can provoke improper choices (for example, suggesting incapable or dangerous drugs), asset squander and confused future examination.

\section{Kinds of Reporting Bias}

$>$ Citation inclination: amassing your assessment concerning contemplates that you find in the references of different assessments.

$>$ Language inclination: ignoring research not disseminated in your local Language.

Location tendency: certain reports or studies are more elusive than others. For instance, considers that are dispersed in journals may be recorded higher in data bases.

$>$ Duplicate circulation inclination: contemplates that are disseminated in more than one spot may get more weighting than different explores.

$>$ Outcome declaring inclination: express uncovering of unequivocal results, for example, results that paint a relationship in a good light.

$>$ Publication inclination: examines with positive disclosures have more freedoms to be appropriated and conveyed even in less time than concentrates with negative divulgences or no huge disclosures.

$>$ Time slack: two or three assessments put aside a long exertion to be circulated, particularly when they show no impact or have irksome outcomes. Studies that are positive or newsworthy are appropriated a lot quicker.

Adapt: The Committee on Publication Ethics is centered around training and supporting editors, distributers and people worried in distribution morals with the purpose of moving the way of life of distributing towards one where good practices transforms into a normal part of the distributing society. For over twenty years COPE has created to help people all through the globe, from each instructive field. Adapt individuals are generally editors, in any case conjointly distributers and all associations and people. eLearning course by COPE gives incredible steerage on subjects including: counterfeiting, adulteration, creation, irreconcilable situations and unfortunate behavior. Fundamental point of COPE is to make moral practices a piece of distribution culture. It will in general state about current conversations and issues at events and in bulletins and articles. Adapt engages key gatherings inside the insightful 
distributing method to share their data and thoughts to insist moral practices become a part of the way of life itself.

Friend audit plays a huge assignment in making certain the trustworthiness of the academic record. The training depends to an outsized degree on trust, and needs that everybody concern acts constantly and morally. Companion analysts have a central and colossal effect inside the pattern of friend audit measure, at any rate on numerous occasions re-appearance of the part with no course and will not think about their ethical responsibilities. The COPE Ethical Guidelines for Peer Reviewers dispatched the essential norms and standards to that all companion commentators ought to finish all the friend survey measure.

\section{Fundamental standards to which peer reviewers should follow}

exclusively adjust to overview compositions for which they have the subject capability expected to hold out a correct assessment and which they will survey in time respect the protection of the friend audit and not unveiling the subtleties identified with the original copy until it is distributed and delivered by the diary not use data obtained during the companion survey measure for their own or some other association's advantage or misfortune or shame others articulate all probably conflicting interests, searching for recommendation from the diary in the occasion that they're unsure whether one thing involves an appropriate interest denying the companion audit to be influenced by the sources of a unique duplicate, by the ethnicity, religion, political reasoning, sexual direction or characteristics of the makers, or by business issues be evenhanded and valuable in their surveys, disregarding being adversarial or red hot and from making defaming or uncomplimentary individual comments perceive that friend survey is essentially a correlative endeavor and endeavor to hold out their sensible degree of investigating and during a helpful way give diaries with individual and expert data that is correct and a certified portrayal of their experience recognize that emulate of someone else all through the audit cycle is viewed as extreme offense

WAME: Established in 1995, WAME (enunciated "whammy") is a 501(c)(3) philanthropic willful relationship of editors of companion investigated clinical diaries from countries all through the globe who solicitation to support overall interest among and training of clinical diary editors. Enlistment in WAME is free and every powerful publication supervisor of friend checked on clinical diaries is able to join. Enlistment is besides out there to pick understudies in diary article strategy and companion survey. WAME has more than 1830 people addressing to 1,000 diaries from 92 countries (beginning at July 27, 2017).

\section{Objectives of WAME are listed below}

Overall composed exertion and correspondence among editors of friend examined clinical journals is upheld by WAME.

> To improve circulation principles, to show tendency in clinical modifying through edu., selfinvestigation and self-rule.

$>$ Research on the rules and practice of clinical modifying is locked in by WAME.

> WAME's structure up individuals conjointly avowed that individuals from WAME will be given to high good and sensible guidelines in the mission for the subsequent standard targets:

$>$ To disperse novel, basic, all around reported companion assessed articles on clinical and lab research.

$>$ To proceeded with direction in essential and clinical sciences to help showed clinical dynamic.

$>$ To help specialists with remaining taught in one or extra areas of medication.

$>$ To improve general flourishing all around by making the norm of treatment, unwellness obstacle and clinical investigation better.

$>$ To create capable and changed discussion on questionable issues and frameworks affecting medication and clinical advantages.

$>$ To advance buddy review as a vehicle for reasonable talk and quality affirmation in prescription and to help attempts with improving companion overview. 
$>$ To achieve the absolute best degree of good clinical news inclusion.

> To advance self-review and reliably/deductively kept up progress inside the modifying cycle.

$>$ To produce disseminations that are a lot of arranged, sensible and pleasurable to inspect.

$>$ To envision major issues, bothers and examples in drug and clinical benefits.

$>$ To support perusers concerning non-clinical bits of solutions and general flourishing, correspondingly as political, intelligent, great, natural, monetary, unquestionable and social issues.

These objectives give a clinical journal a social commitment to make improvements in present human sicknesses and secure the genuineness of sciences.

Beyond reconciliation circumstances: Conflicts of interest may be portrayed as "conditions that settle on a threat that capable choices or exercises with respect to a fundamental interest will be unduly influenced by a discretionary interest". Comprehensively conveyed, the central responsibility of the inspector in assessment is to get probably genuine outcomes, while advancing and getting the decency of investigation.

\section{Managing conflicts of interest:}

It can immediately be seen that the degree and assortment of questions tends to a colossal association challenge, and dependence upon uncommon point and amazing character is missing to address these issues. These get the going together with:

$>$ Regulation of the individual

$>$ Design and rule of the investigation cycle

$>$ Critical evaluation of the investigation thing

"The fix to reputation, power, authoritative issues, and eagerness exploited by journals in the twentieth century was enthusiastic companion overview... . Transparency and openness are the weapons they have powerfully passed on. Companion study is the other mind blowing protection against hostile conditions"

\section{Professional Ethics}

As shown by Your Dictionary "Capable ethics is portrayed as the individual and corporate rules that manage direct inside the setting of a particular calling".

"Teachers help understudies with learning the academic basics, anyway they similarly show critical life practices by setting a positive model. As genuine models, teachers ought to follow a specialist code of ethics. This ensures that understudies get a sensible, real and strong preparing. A specialist code of ethics follows teachers' basic obligations to their understudies and describes their work in understudies' lives. Above all, educators should show dependability, unbiased nature and good direct in the investigation lobby and in their lead with watchmen and partners".

\section{Teacher's values and ethical principles}

The focal point of showing involves four central characteristics: respectability, trustworthiness, fairness and commitment and opportunity. Teachers are equipped for their own characteristics, yet in their work, educators' obligation is joined to their fundamental endeavor and its standards, for instance, institution and the curriculum. They ensure that understudies and their people's social orders and world perspectives are regarded similarly and that nobody is mishandled dependent upon them.

\section{Plagiarism Detection Tools}

Show Your Students the Importance of Authenticity

"Turnitin's equivalence checking consolidates with Canvas impeccably. It works honorably as an instrument for training understudies about the fitting use of sources, revamping, over-refering to, and refering to. We have used Turnitin answers for quite a while with extraordinary results and positive contribution from understudies." 
All universities in India, public and private, have been given key acceptance to hostile to copyright infringement programming Urkund August 2. Last support to get to the Swedish programming will start from September 1, 2019, as exhibited by a notification from the University Grants Commission (UGC). UGC is giving freed from cost Anti-forging programming (Urkund) to all organization similarly as private universities.

The Urkund composing PC programs was investigated an in general sensitive association. While Turnitin is much more generally utilized by and large scholastics, it was discovered to be on various events even more costly without a proportionate expansion in features or steadfastness.

\section{Similarities and offense}

There are no orders for minor likenesses, up to $10 \%$ of the report. If a recommendation or postulation has likenesses up to $40 \%$, it is viewed as a level 1 offense and understudies will be moved closer to present a reconsidered understanding inside a half year. In a level 2 offense, the similarities are some spot in the extent of $40 \%$ and $60 \%$, and the understudy will be suspended from presenting a changed substance for one year. Similitudes above $60 \%$ are viewed as a level 3 offense and will incite release, with understudy selection for that program being dropped.

If there arises an occasion of insightful burglary in instructive and appraisal flows, a level 1 offense will accomplish being moved nearer to pull back the primary copy. If there should arise an occasion of level 2, the accountable party will in like way be denied the favorable position to one yearly development, and won't be permitted to coordinate any Masters, M.Phil or Ph.D understudy for a drawn out period. A level 3 offense will accomplish refusal of two yearly amplifications and debarment from research the board for a long time.

Rehashed offenses will accomplish more basic level orders, including suspension and end. In the event that copyright infringement is perceived after a degree or credit has been truth be told, that will be suspended for a set period.

\section{Academic Standards}

An UGC board on improving assessment culture, headed by past Indian Institute of Science manager P. Balaram, admonished that such focal principles couldn't substitute the essential for institutional care.

"Forging and data control are issues of exceptional concern, which hurt the legitimacy of assessment oozing from our associations. Establishments ought to accept the obligation for ensuring educational standards and for focusing, to the two understudies and work force, the meaning of keeping up the best assumptions for dependability in academic investigation," said the report introduced by the board a month prior.

"Joined standards and rules, constrained across an enormous and arranged high level training structure, can't fill in as a substitute for extreme and attentive internal insightful cycles at our foundations," it said.

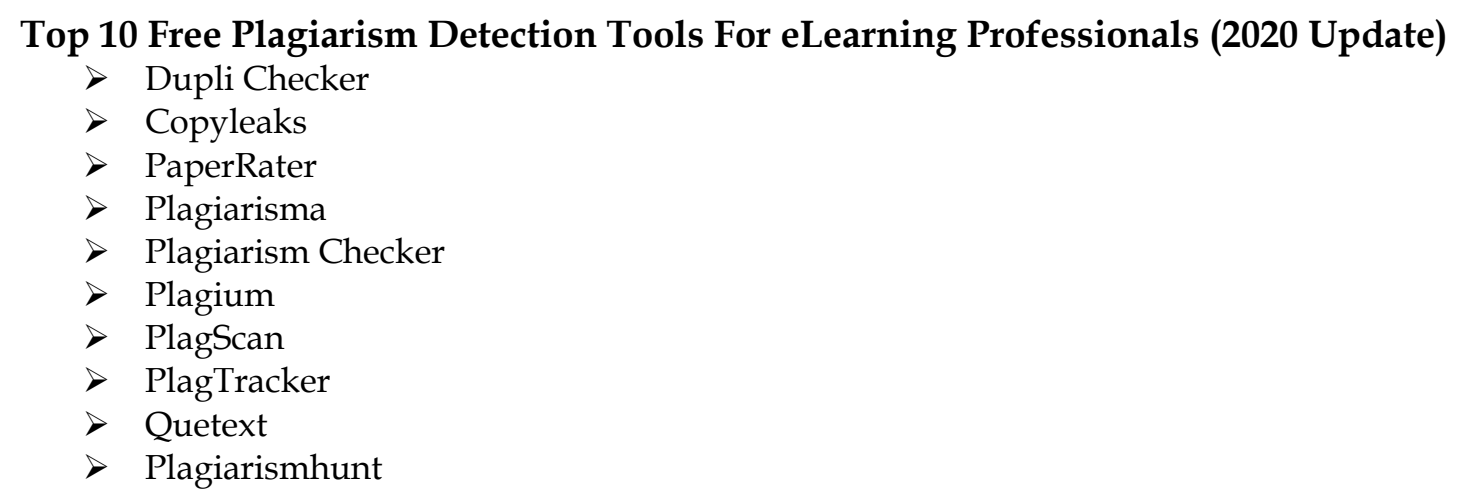




\section{CONCLUSION}

Ethics and characteristics are two philosophical insights that have become the backbone of human civilization. The ethical standard structures a sensation of good and horrendous, while the valuation system help humankind shield and seek after basic things. Moral standard develops the significant principle on which the law and the legal framework work. It describes which exercises ought to be considered as right coordinates and which exercises ought to have been considered as misguided practices. Moral standards portray conventionality. Thusly, even every legal plan needs to pass the ethical standard under the watchful eye of transforming into any new law. Instead of the ethical standard, the valuation system centers around basic things for the duration of regular daily existence. It's definitely not a regular standard. Along these lines, the valuation of any thing or theory has a substitute importance to different people. It in like manner changes with time. Anything significant today may not hold its valuation later on. There are different kinds of degenerate practices that producers resort to, at times purposely and periodically unexpectedly. Noticing circulation ethics chose in this will drive perusers to intentionally evade such offense and perform sensible good investigation and practice appropriations. The COPE and WAME gives clear rules and steps to be taken when each the sum of the recently referenced pitiful activities is seen. Creation and bending are phenomenally affirmed kinds of assessment offense. The utilization of actually disseminated work by another producer in one's own creation without assent, credit, or authentication and misleadingly passing it as one's own work is implied as abstract burglary. This is the most by and large saw sort of intelligent offense in arrangement creating.

\section{REFERENCE}

1. Yadav, P. (2020, September 20). Difference Between Ethics and Values (With Table). Ask Any Difference. https:/ / askanydifference.com/difference-between-ethics-and-values/

2. McCombs School of Business at the University of Texas at Austin. (2018, December 12). Moral Philosophy. Ethics Unwrapped. https://ethicsunwrapped.utexas.edu/glossary/moralphilosophy

3. Peter Singer, Article Title: Ethics, Website Name: Encyclopædia Britannica, Publisher:Encyclopædia Britannica, inc. Date Published:January 13, 2020, https://www.britannica.com/topic/ethics-philosophy

4. Singer, P. (2020, January 13). ethics | Origins, History, Theories, \& Applications. Encyclopedia Britannica. https://www.britannica.com/topic/ethics-philosophy

5. BBC - Ethics - Introduction to ethics: Ethics: a general introduction. (n.d.). BBC. Retrieved November 2020, from http:/ / www.bbc.co.uk/ethics/introduction/intro_1.shtml

6. Ghosh, P. (2015, September 11). Useful Notes on the Nature of Moral Judgment. World's Largest Collection of Essays! Published by Experts. https://www.shareyouressays.com/knowledge/useful-notes-on-the-nature-of-moraljudgment/113095

7. Carpi, Anthony., Egger, Anne E.(2009). Scientific Ethics. Visionlearning Vol. POS-2 (5), 2009.

8. NOTE OF UNIT: III RESEARCH AND RESEARCH ETHICS Compiled by Dr. Narendrasinh B. Chauhan Professor and Head Department of Extension Education B.A.College of Agriculture, AAU, $\quad$ Anand http://www.aau.in/sites/default/files/Unit\%203\%20RESEARCH\%20AND\%20RESEARCH $\% 20$ ETHICS\%20(Repaired).pdf

9. Stanley G. Korenman M.D.Teaching the Responsible conduct of research in Human (RCRH) $\begin{array}{llllll}\text { Chapter 1: The ethical basis of RCRH } & \end{array}$ https://ori.hhs.gov/education/products/ucla/chapter1/Chapter1.pdf https://ori.hhs.gov/education/products/ucla/chapter1/page02.htm

10. Stanley G., K. (n.d.). Chapter 1 - Research Integrity. RCR. Retrieved November 2020, from https://ori.hhs.gov/education/products/ucla/chapter1/page02.htm

11. What is Research Misconduct? Part 3: Fabrication by Eliesbik 2019 Office of Research Integrity https:/ / scienceintegritydigest.com/2019/05/29/ what-is-research-misconduct-part-3fabrication/ 
12. What is Research Misconduct? Part 3: Falsification by Eliesbik 2019 Office of Research Integrity https:// scienceintegritydigest.com/2019/05/28/what-is-research-misconduct-part-2falsification/

13. Updated by Claus Tonsberg on 21 August 2020, Responsible editor: Merian Skouw HaugwitzHardenberg-Reventlow framework/principles_for_good_scientific_conduct

14. Irving Hexham, Department of Religious Studies, University of Calgary (c) Copyright Irving Hexham 1992, 1999, 2005, "The Plague of Plagiarism: Academic Plagiarism Defined" http:// people.ucalgary.ca/ hexham/content/articles/plague-of-plagiarism.html

15. Redundant Publication. (n.d.) Segen's Medical Dictionary. (2011). Retrieved September 202020 from https://medical-dictionary.thefreedictionary.com/Redundant+Publication

16. Overlapping publications and self-plagiarism: Plagiarism and good citation practice by Forskerportalen.DK, Forskerportalen (the Researcher Portal) https:// forskerportalen.dk/en/overlapping-publications-and-self-plagiarism/

17. Forskerportalen.DK. (n.d.). Overlapping publications and self-plagiarism - Forskerportalen.dk. Forskerportalen (the Researcher Portal). Retrieved August 2020, from https://forskerportalen.dk/en/overlapping-publications-and-self-plagiarism/

18. FACTSHEET: Salami Slicing. (n.d.).Retrieved August 2020 from ethics.elsevier.com https://www.elsevier.com/_data/assets/pdf_file/0011/653888/Salami-Slicing-factsheetMarch-2019.pdf

19. Stephanie Glen. (n.d.) "Reporting Bias: Definition and Examples, Types". Retrieved September 2020 From StatisticsHowTo.com: Elementary Statistics for the rest of us! https://www.statisticshowto.com/reporting-bias/

20. About COPE | COPE: Committee on Publication Ethics. (n.d.). Publication Ethics Org. Retrieved September 2020, from https:// publicationethics.org/about/our-organisation

21. "COPE Ethical Guidelines for Peer Reviewers", Irene Hames on behalf of COPE Council March 2013, v.1 COPE Committee of Publication Ethics. Retrieved September 2020 from https://static.primary.prod.gcms.the-infra.com/static/site/journals/document/Ethicalguidelines-for-peer-reviewers0.pdf?node $=$ fb91fa16958083d759f9\&version=111868:23c8dd04939fc5912433

22. About Us || WAME. (n.d.). Www.Wame.Org. Retrieved August 2020, from https://www.wame.org/aboutus

23. PROFESSIONAL-ETHICS | 1 Definitions of Professional-ethics - YourDictionary. (n.d.). Your dictionary.Com. Retrieved August 2020, from https://www.yourdictionary.com/professionalethics

24. P. (2014, February 7). About. Www.Education.Gov.Gy. https://www.education.gov.gy/web/index.php/about-moe

25. Teacher's values and ethical principles. (n.d.). Trade Union of Education, OAJ. OAJ- Areena. Retrieved September 2020, from https://www.oaj.fi/en/education/ethical-principles-ofteaching/teachers-values-and-ethical-principles/\#teachers-and-plurality

26. Glasson, V. (2017, September 3). 6 Ways to Spot a Predatory Journal. Rx Communications. https://www.rxcomms.com/blog/6-ways-spot-predatory-journal/

27. Sehdeep. (2013, August 10). Some Open Access Initiatives in India. Open Access Initiatives: India. https://sehdeepkaur.wordpress.com/2013/08/10/some-open-access-initiatives-in-india/

28. Guides: Open access: Open access. (n.d.). Victoria University of Wellington Te Herenga Waka, The Library Te Pataka Korero. Retrieved August 2020, from https:/ /libguides.victoria.ac.nz/c.php?g=622049\&p=4333128

29. Sherpa services. (n.d.). Jisc. Retrieved August 2020, from https://www.jisc.ac.uk/sherp

30. Caplan, A. L. (2007). Halfway there: the struggle to manage conflicts of interest. Journal of Clinical Investigation, 117(3), 509-510. https:/ / doi.org/10.1172/jci31565

31. Romain P. L. (2015). Conflicts of interest in research: looking out for number one means keeping the primary interest front and center. Current reviews in musculoskeletal medicine, 8(2), 122-127. https://doi.org/10.1007/s12178-015-9270-2

32. Turnitin Similarity | Best-in-Class Plagiarism Checker. (n.d.). Turnitin. Retrieved August 2020, from https://www.turnitin.com/products/similarity 
33. Correspondent, S. (2019, August 3). Indian universities get free access to Urkund software. The Hindu. https://www.thehindu.com/news/cities/Delhi/indian-universities-get-free-access-tourkund-software/article28810881.ece

34. Pappas, C. (2020, June 25). Top 10 Free Plagiarism Detection Tools For eLearning Professionals (2020 Update). ELearning Industry. https://elearningindustry.com/top-10-free-plagiarismdetection-tools-for-teachers

35. Sengupta, S., \& Honavar, S. G. (2017). Publication ethics. Indian journal of ophthalmology, 65(6), 429-432. https://doi.org/10.4103/ijo.IJO_483_17

36. Jain, Anil $\mathrm{K}(2010)$ "Editorial: Ethical issues in scientific publication" Indian Journal of Orthopaedics, 44(3): 235-7, Source-PubMed DOI: 10.4103/0019-5413.65133

37. Principles for good scientific conduct - DTU. (n.d.). www.dtu.dk. Retrieved August 21, 2020, from framework/principles_for_good_scientific_conduct

38. Hexham, I. (2005). Academic Plagiarism. University of Calgary. http:/ / people.ucalgary.ca/\%7Ehexham/content/articles/plague-of-plagiarism.html

39. Anthony Carpi, P., \& Anne E. Egger, P. (2017, February 12). Scientific Ethics: Process of Science. Retrieved from https://www.visionlearning.com/en/library/Process-of-Science/49/ScientificEthics/161

40. (n.d.). Retrieved from http://www.wz.uw.edu.pl/portale/journal-of-banking-and-financialeconomics/dzial/ethical-standards-and-authors-copyrights 